\title{
Effects of Th1 and Th2 cytokines on cytokine production and ICAM-1 expression on synovial fibroblasts
}

Jörg F Schlaak, Andreas Schwarting, Percy Knolle, Karl-Hermann Meyer zum Büschenfelde, Werner Mayet

\begin{abstract}
Objectives-To investigate the influence of the Th1 and Th2 lymphokines interleukins (IL)-4 and IL-13, interferon gamma (IFN $\gamma$ ), and several monokines on the adhesion of mononuclear cells to synovial fibroblasts and intercellular adhesion molecule-1 (ICAM-1) expression and cytokine production of synovial fibroblasts in patients with osteoarthritis. Methods-Synovial fibroblasts were isolated from patients with osteoarthritis and

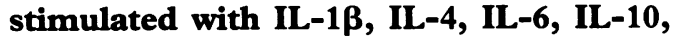
IL-12, IL-13, tumour necrosis factor $\alpha$ (TNF $\alpha$ ), and IFN $\gamma$. Subsequently, we determined the production of IL-1 $\alpha$, IL-

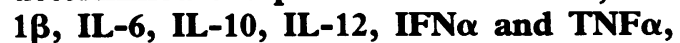
and the expression of ICAM-1 lymphocyte function associated antigen 3 (LFA-3), BB7, and major histocompatibility complex class II molecules on these cells. Furthermore, the adhesion of freshly isolated mononuclear cells from the peripheral blood was tested using a colourimetric cell-cell adhesion assay.

Results-Only production of IL-6 and the expression of ICAM-1 were observed. IL$1 \beta$ and TNF $\alpha$ were the most potent stimulatory mediators of both cytokine production and ICAM-1 expression. IL-4 and IL-13 had differential effects as they upregulated cytokine production but downregulated IFN $\gamma$ induced ICAM-1 expression. In functional adhesion assays, TNF $\alpha$, IL-1 $\alpha$ and, to a lesser extent, IFNy led to increased adhesion of mononuclear cells, whereas IL-4 and IL-13 had no effect.
\end{abstract}

Conclusions-Our data indicate that Th1 and Th2 lymphokines can modulate the function (cytokine production and expression of adhesion molecules) of synovial fibroblasts.

(Ann Rheum Dis 1995; 54: 560-565)

There is increasing evidence that inflammatory reactions in the joint are regulated by cytokines secreted from $\mathrm{T}$ lymphocytes, monocytes, granulocytes, endothelial cells, and synoviocytes. Cytokines secreted by these cells may lead to exacerbation or suppression of an inflammatory process. In previous studies increased concentrations of interleukin (IL)-1,
IL-6, IL-8, tumour necrosis factor $\alpha$ (TNF $\alpha$ ), transforming growth factor $\beta$ (TGF $\beta$ ), and granulocyte macrophage colony stimulating factor (GM-CSF) have been found in the synovial fluid of patients with osteoarthritis, rheumatoid arthritis, or spondyloarthropathies. ${ }^{1-4}$ IL-4, IL-10, IL-12, and interferon gamma (IFN $\gamma$ ) are also detectable (Schlaak et $a l$, manuscript in preparation). In addition, the IL-1 receptor antagonist, soluble $T N F \alpha^{5}$ and soluble IL-1 receptor that may function as cytokine antagonists ${ }^{6}$ are present in synovial fluid.

Although the interaction between monocytes and fibroblasts in rheumatoid synovium has been extensively studied, little is known about the interaction between $T$ cells and fibroblasts. In vitro studies have demonstrated that human $\mathrm{T}$ cells have the ability to adhere to synovial fibroblast like cells. ${ }^{7}$ Synovial fibroblasts may be not only the target but also the producers of some of the cytokines mentioned above. Previous studies have demonstrated that synovial fibroblasts produced IL- $6,{ }^{8} \mathrm{IL}-8,{ }^{9}$ monocyte chemoattractant protein, IP-10, ${ }^{10} \mathrm{TGF} \beta$, basic fibroblast growth factor, GM-CSF ${ }^{11}$ and leukaemia inhibitory factor. ${ }^{12}$

$T$ lymphocytes play a critical role in the induction and perpetuation of rheumatoid arthritis and spondyloarthropathies. ${ }^{13}$ It has been well established that the function of human $T$ lymphocytes is dependent on their secreted cytokine profile. They can be subdivided into different subgroups according to the secretion of the immunoregulatory cytokines IL-4 and IFN $\gamma$. Human T cells that produce IFN $\gamma$ but no IL-4 are termed Th1 cells. These cells are able to mediate cellular immune reactions such as delayed type hypersensitivity, ${ }^{14}$ and suppress humoral reactions. ${ }^{15}$ They are involved in reactive arthritis, ${ }^{16}$ psoriasis vulgaris and arthropathia psoriatica, ${ }^{17}$ and immune reactions directed against various bacteria. ${ }^{18} 19 \mathrm{~T}$ cells that produce IL-4 but no IFN $\gamma$ are termed Th2 cells. These cells are thought to suppress cellular reactions and give 'help' for humoral immune responses. They seem to be involved in allergic reactions. ${ }^{20}$

Several novel immunoregulatory cytokines have been identified. IL-10, initially designated as cytokine synthesis inhibitory factor, ${ }^{21}$ is produced by B cells, ${ }^{22} \mathrm{~T}$ cells, ${ }^{23}$ monocytes, ${ }^{24}$ and keratinocytes. ${ }^{25}$ It can effectively downregulate monokine production ${ }^{24}$ and lymphokine 
production by $\mathrm{T}$ cells when they are stimulated by monocytes. ${ }^{26} 27$ Conversely, proliferation and survival of $B$ cells are enhanced. ${ }^{28}$ In the murine system, IL-10 is produced by Th2 but not Th1 cells, and can suppress proliferation of Th1 but not Th2 cells. In humans, it does not seem to have the same cross regulatory properties, as it is secreted by all $\mathrm{T}$ cell subsets and is able to downregulate proliferation and cytokine production of Th1 and Th2 cells. IL12 , initially described as natural killer cell stimulatory factor, is produced by $B$ cells ${ }^{29}$ and monocytes. ${ }^{30}$ Apart from its ability to stimulate IFN $\gamma$ production by natural killer cells and T cells, ${ }^{31}$ IL-12 can induce Th1 type immune reactions, when present at the first stimulation of a naive $\mathrm{T}$ cell. ${ }^{32} \mathrm{Few}$ data are available concerning IL-13, which is produced by $B$ cells and Th2 lymphocytes. ${ }^{33}$ Human IL-13 can downregulate cytokine production by monocytes, and induce proliferation and differentiation $^{34}$ and IL-4 independent IgE and IgG4 production and CD23 expression by $B$ cells. ${ }^{35}$ It has been postulated that IL-4 and IL-13 share a receptor component which is important for signal transduction. ${ }^{38}$

We investigated the effects on synovial fibroblasts, of immunoregulatory cytokines that are detectable (with the exception of IL-13, for which no specific enzyme linked immunosorbent assay (ELISA) or bioassay is currently available) in the synovial fluid of patients with different forms of arthritis. In addition, we tested the hypothesis that IL-4 and IL-13 share a receptor component, and determined the synovial fibroblast expression of adhesion molecules for $\mathrm{T}$ lymphocytes, granulocytes and monocytes.

\section{Materials and methods}

REAGENTS

Recombinant human Escherichia coli-derived IL-1 $\beta$, IL-4, IL-6, IFN $\gamma$ (purchased from PBH, Hannover, Germany), IL-10 (purchased from Genzyme, Cambridge, MA), IL-12 (kindly provided by Genetics Institute, Cambridge, MA), IL-13 (kindly provided by Dr A Minty, Sanofi Elf Bio Recherches, Labege, France), TNF $\alpha$ (kindly provided by Knoll AG, Ludwigshafen, Germany) and soluble human IL-4 receptor (kindly provided by Behring Werke, Marburg, Germany) were used as highly purified proteins. Culture medium for synovial fibroblasts was M 199 (Biochrom, Berlin, Germany) supplemented with $5 \%$ fetal calf serum (FCS), $2 \mathrm{mmol} / \mathrm{l}$ L-glutamine (Sigma, St Louis, MO), $50 \mu \mathrm{g} / \mathrm{ml}$ gentamicin (Gibco) and $17 \mathrm{U} / \mathrm{ml}$ heparin. The neutralising anti-IL-4 antibody was a kind gift from $\mathrm{Dr} G$ Le Gros. Anti-intercellular adhesion molecule-1 (ICAM-1), anti-lymphocyte function associated antigen-3 (LFA-3), and anti-major histocompatibility complex (MHC) class II antibodies were purchased from Immunotech, Marseille, France. AntiBB7 antibody was kindly provided by $T$ Yokuchi.
CELLS

Synovial tissues were obtained from patients with osteoarthritis, at the time of joint replacement surgery, and dissected and minced into $3-5 \mathrm{~mm}^{3}$ pieces as previously described. ${ }^{36}$ The minced tissue was incubated in Hanks's balanced salt solution containing $0 \cdot 2 \%$ collagenase II (Sigma) for 60 minutes with occasional stirring. Cellular material was filtered through several sieves from $250 \mu \mathrm{m}$ up to $90 \mu \mathrm{m}$ pore size. Samples were centrifuged for 10 minutes at $400 \mathrm{~g}$ and resuspended in culture medium. The resulting isolated cell suspension contained a heterogenous cell population, which was plated into a $75 \mathrm{~mm}^{3}$ culture flask (Greiner, Nürtingen, Germany).

\section{CELL IDENTIFICATION}

The cells were grown to confluence and passaged with a split ratio of $1: 3$. After the third passage the cells revealed a homogeneous fibroblast like morphology. Isolated cells were characterised using anti-CD14, anti-von Willebrand factor, anti-Ulex-lectine, and 5B5, a fibroblast marker (DAKO, Hamburg, Germany). Only 5B5 showed weak stainingother cell markers were negative.

\section{ASSAYS FOR CYTOKINE PRODUCTION}

These assays were performed in 96 well flat bottomed microtitre plates (Greiner). Synovial fibroblasts were stimulated by incubating $2 \times 10^{4}$ cells with the respective cytokines in a volume of $200 \mu \mathrm{l}$ per well. Supernatants were harvested after 48 hours, stored immediately at $-20^{\circ} \mathrm{C}$, and thawed before testing. The amounts of IL-1 $\alpha$, IL-1 $\beta$, IL-4, IL-6, IL-10, IL-12, IFN $\alpha$ and TNF $\alpha$ in the culture supernatants were determined using cytokinespecific ELISAs as previously described. ${ }^{16}$ The lower limit of detection for each assay was approximately $50 \mathrm{pg} / \mathrm{ml}$ (IL-1 1 : $5 \mathrm{pg} / \mathrm{ml}$; IL-6: $1 \mathrm{U} / \mathrm{ml}$ ). All assays were performed in triplicate and repeated at least three times. A standard curve was prepared in each assay.

\section{IL-4 AND IL-13 RECEPTOR(S)}

Synovial fibroblasts $\left(2 \times 10^{4}\right)$ were incubated with $20 \mathrm{ng} / \mathrm{ml} \mathrm{IL-4}$ or $20 \mathrm{ng} / \mathrm{ml} \mathrm{IL-13}$ in the presence or absence of the human IL-4 receptor molecule $(5 \mu \mathrm{g} / \mathrm{ml})$. After 24 hours, supernatants were harvested and tested for the amount of IL-6 using a cytokine specific ELISA. The experiments were performed in triplicate.

FLUORESCENCE ACTIVATED CELL SORTER (FACS) ANALYSIS

Synovial fibroblasts $\left(5 \times 10^{5}\right)$ were incubated with the respective cytokines in 24 well plates (Greiner) in a volume of $500 \mu$ l. After 24 hours the cells were removed from the plates by trypsinisation using trypsin/EDTA (Biochrom), washed and incubated with the desired primary antibody at $4^{\circ} \mathrm{C}$ for 60 minutes. After washing with phosphate 
buffered saline (PBS) containing $1 \%$ FCS and $0 \cdot 2 \%$ sodium azide, cells were counterstained with saturating amounts of fluorescein isothiocyanate (FITC) labelled goat antimouse $\mathrm{Ig}$ and incubated at $4^{\circ} \mathrm{C}$ for 30 minutes. After further washing, cells were fixed with $1 \%$ paraformaldehyde in PBS. Non-specific fluorescence was assessed by staining with irrelevant isotype matched $\mathrm{MAb}$, followed by FITC-anti Ig. Samples were analysed with a FACScan (Becton Dickinson, Mountain View, CA) using forward and orthogonal light scatter to select viable cells. Data for 3000 cells were collected. All experiments were repeated three times.

\section{ADHESION ASSAY}

Functional adhesion assays were performed as previously described. ${ }^{37}$ Briefly, synovial fibroblasts were seeded into 96 well plates at a concentration of $1 \times 10^{5}$ cells per well and incubated with various cytokines for $\mathbf{4 8}$ hours. Mononuclear cells were isolated from the peripheral blood (PBMC) of healthy donors by Ficoll-Hypaque gradient centrifugation and biotinylated using sulpho-NHS-biotin (No 21217, Pierce, Rockford, IL) at a concentration of $0.2 \mathrm{mg} / \mathrm{ml}$. These cells were labelled with streptavidin conjugated horseradish peroxidase (Dako) at a dilution of 1:500 in PBS. Supernatants were removed from the fibroblasts and the labelled PBMC were seeded into the plate at a concentration of $5 \times 10^{5}$ cells/well in PBS containing $1 \mathrm{mmol} / 1$ calcium, $1 \mathrm{mmol} / \mathrm{l}$ magnesium, $1 \mathrm{mmol} / 1$ mangan and $50 \mathrm{mmol} / 1$ mannose. After two hours of incubation at $37^{\circ} \mathrm{C}$, non-adherent PBMC were removed by washing in PBS and an ELISA reaction was performed as described. ${ }^{16}$ Each experiment was performed in triplicate.

\section{Results}

EFFECTS OF IL-1 $\beta, \mathrm{IL}-4, \mathrm{IL}-10, \mathrm{IL}-12, \mathrm{IL}-13, \mathrm{IFN} \gamma$, AND TNF $\alpha$ ON CYTOKINE PRODUCTION The table shows the effects of IL-1 $1 \beta, \mathrm{IL}-4, \mathrm{IL}-$ 10, IL-12, IL-13, IFN $\gamma$, and TNF $\alpha$ on cytokine production by synovial fibroblasts, tested using cytokine specific ELISAs. Only IL- 6 was detectable in the supernatants of cells stimulated with IL-1 $\beta$ IL-4, IL13, IFN $\gamma$, and TNF $\alpha$. The most potent inducers of IL-6 production were IL- $1 \beta$ and TNF $\alpha$; IL-4 and IL-13 had moderate effects. In high con- centrations, IFN $\gamma$ induced small amounts of IL-6 (fig 1).

EFFECT OF SOLUBLE IL-4 RECEPTOR ON IL-4 AND IL-13 STIMULATED INDUCTION OF IL-6 ON SYNOVIAL FIBROBLASTS

Stimulation of synovial fibroblasts with IL-4 or IL-13 in the absence or presence of the soluble human IL-4 receptor showed that IL-6 production induced by IL-4, but not that induced by IL-13, can be blocked by the soluble IL-4 receptor molecule (fig 2 ).

EXPRESSION AND MODULATION OF EXPRESSION OF ADHESION MOLECULES (FACS ANALYSIS) Initial experiments in which cells were stained for ICAM-1, LFA-3, BB7 and MHC class II using FACS analysis showed that only ICAM-1, not LFA-3, BB7, or MHC class II molecules, were expressed on these cells (data not shown). ICAM-1 was constitutively expressed, although the degree varied from experiment to experiment; average expression on unstimulated synovial fibroblasts was 39.3 (SEM 1.7)\%.

Stimulation of synovial fibroblasts with various cytokines to analyse the regulation of the ICAM-1 expression on these cells showed that ICAM-1 expression was upregulated by IL-1 $\beta$, IFN $\gamma$ and TNF $\alpha$, whereas IFN $\gamma$ induced effects were antagonised by IL- 4 and IL-13 (table; fig 3). The effect of IL-4 was specific, as it could be blocked by the addition of a neutralising anti-IL-4 antibody. The effects of both IL-4 and IL-13 were dose dependent.

MODULATION OF ADHERENCE OF PBMC TO SYNOVIAL FIBROBLASTS

$\mathrm{TNF} \alpha$ and IL-1 $\alpha$ were the most potent inducers of PBMC adherence to synovial fibroblasts, followed by IFN $\gamma$ (fig 4). Interestingly, IL-4 did not suppress spontaneous or IFN $\gamma$ induced adherence of PBMC.

\section{Discussion}

We have investigated the effects of immunoregulatory cytokines on cytokine production and ICAM-1 expression by synovial fibroblasts. Our data indicate that IL-

Effects of various cytokines on adhesion of peripheral blood mononuclear cells (PBMC), cytokine production and expression of intercellular adhesion molecule-1 (ICAM-1) on synovial fibroblasts

\begin{tabular}{|c|c|c|c|c|c|c|c|c|c|}
\hline & $\begin{array}{l}\text { IL-1 } \alpha \\
\text { production }\end{array}$ & $\begin{array}{l}I L-1 \beta \\
\text { production }\end{array}$ & $\begin{array}{l}\text { IL-6 } \\
\text { production }\end{array}$ & $\begin{array}{l}\text { IL-10 } \\
\text { production }\end{array}$ & $\begin{array}{l}\text { IL-12 } \\
\text { production }\end{array}$ & $\begin{array}{l}\text { IFNy } \\
\text { production }\end{array}$ & $\begin{array}{l}\text { TNFa } \\
\text { production }\end{array}$ & $\begin{array}{l}\text { ICAM-1 } \\
\text { expression }\end{array}$ & $\begin{array}{l}\text { PBMC } \\
\text { adhesion }\end{array}$ \\
\hline IL-1 $\beta$ & \pm & & +++ & \pm & & \pm & & + & $\begin{array}{l}+++ \\
+\end{array}$ \\
\hline IL-4 & $\stackrel{ \pm}{N D}$ & $\stackrel{ \pm}{N D}$ & ++ & \pm & \pm & $\stackrel{ \pm}{N D}$ & $\stackrel{ \pm}{N D}$ & \pm & $\stackrel{ \pm}{N D}$ \\
\hline $\begin{array}{l}\text { IL-6 } \\
\text { IL-10 }\end{array}$ & \pm & \pm & \pm & & \pm & \pm & \pm & \pm & ND \\
\hline II-12 & \pm & \pm & \pm & \pm & & \pm & \pm & \pm & ND \\
\hline IL-13 & \pm & \pm & $\overline{++}$ & \pm & \pm & \pm & \pm & - & \pm \\
\hline IFN $\gamma$ & $\overline{ \pm}$ & \pm & + & \pm & \pm & \pm & \pm & + & \\
\hline TNF $\alpha$ & & \pm & +++ & $\overline{ \pm}$ & \pm & \pm & & +++ & +++ \\
\hline
\end{tabular}

- = Suppresses cytokine production or expression of ICAM-1; $\pm=$ does not induce or alter cytokine production, expression of ICAM-1, or adhesion of PBMC; $+=$ induces cytokine production, expression of ICAM-1, or adhesion of PBMC. ND $=$ Not determined. 

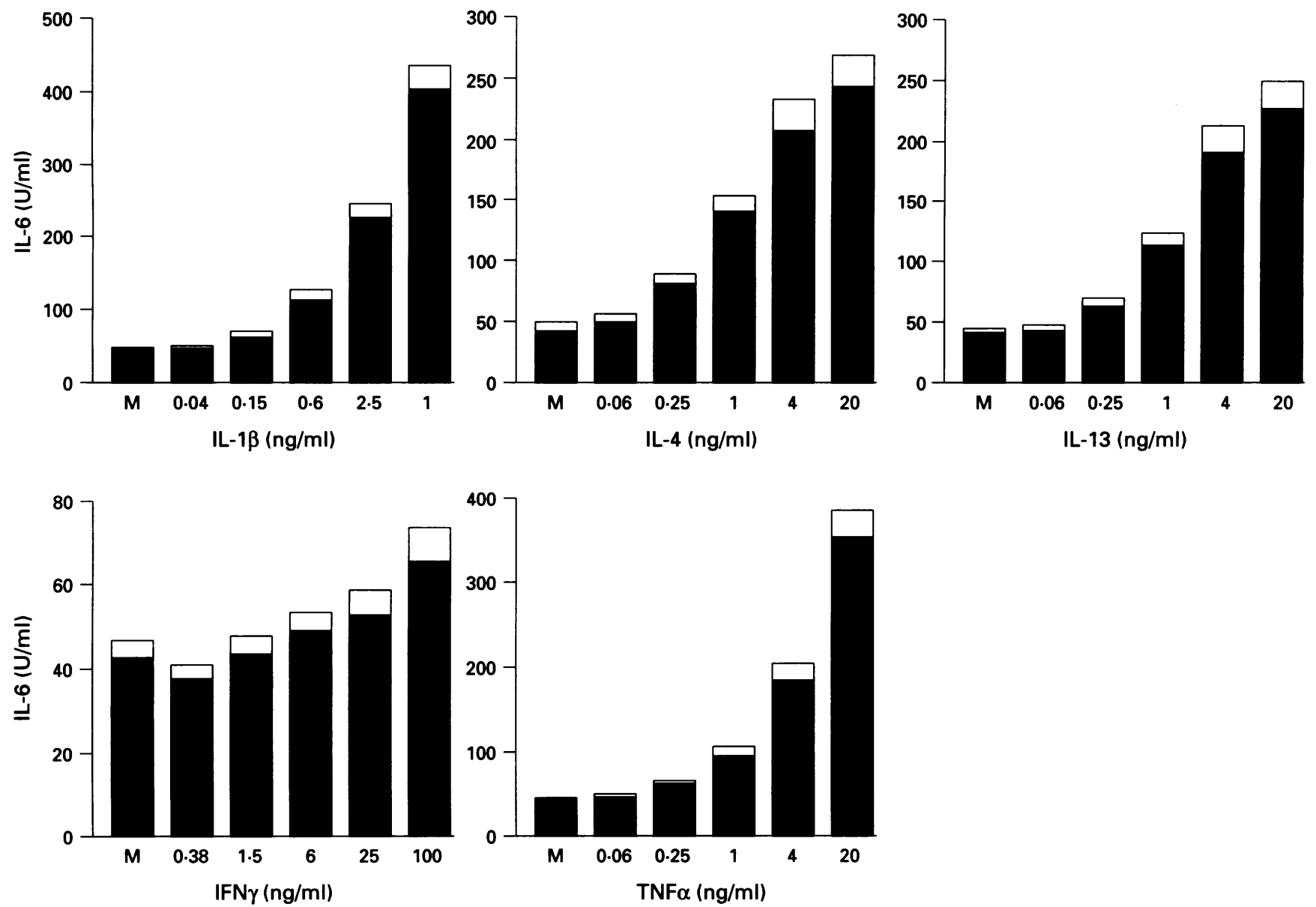

Figure 1 Modulation of IL-6 production by synovial fibroblasts incubated with $I L-1 \beta, I L-4, I L-13, I F N \gamma$, or TNF $\alpha$ in the concentrations indicated. Data are mean values (shaded) and $S D$ (open). $M=$ Medium.

$1 \beta, \mathrm{IL}-4, \mathrm{IL}-13$, and TNF $\alpha$ can induce IL-6 production by these cells, whereas IFN $\gamma$ has only a weak effect. The expression of the adhesion molecule ICAM-1 can be modulated by IL-1 $\beta$, IL-4, IL-13, TNF $\alpha$, and IFN $\gamma$. $\mathrm{TNF} \alpha$ is the most potent inducer of ICAM-1 expression, followed by IFN $\gamma$ and IL-1 $\beta$. Although IL-4 and IL-13 almost completely suppress ICAM-1 expression induced by IFN $\gamma$, they did not suppress IFN $\gamma$ induced increased adherence of PBMC to synovial fibroblasts in a functional assay.

A variety of mediators can be detected in the synovial fluid of patients with osteoarthritis, rheumatoid arthritis, and spondyloarthropathies. These include immunoregulatory cytokines with cross regulatory effects on $T$ lymphocytes, such as IL-4, IL-10, IL-12, and

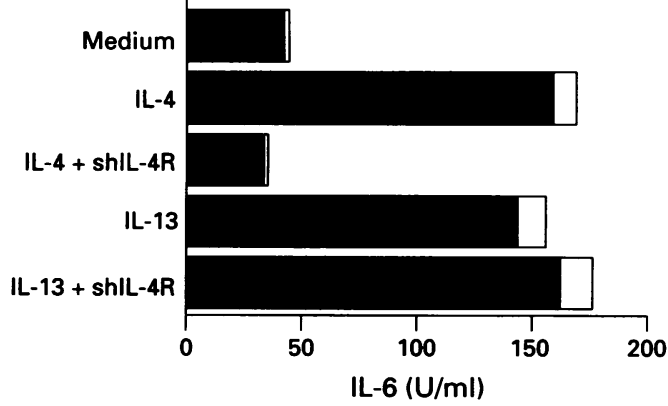

Figure 2 Effect of soluble human $I L-4$ receptor (shIL-4R) on IL-4 and IL-13 stimulated production of IL-6 by synovial fibroblasts. Data are mean values (shaded) and SEM (open).
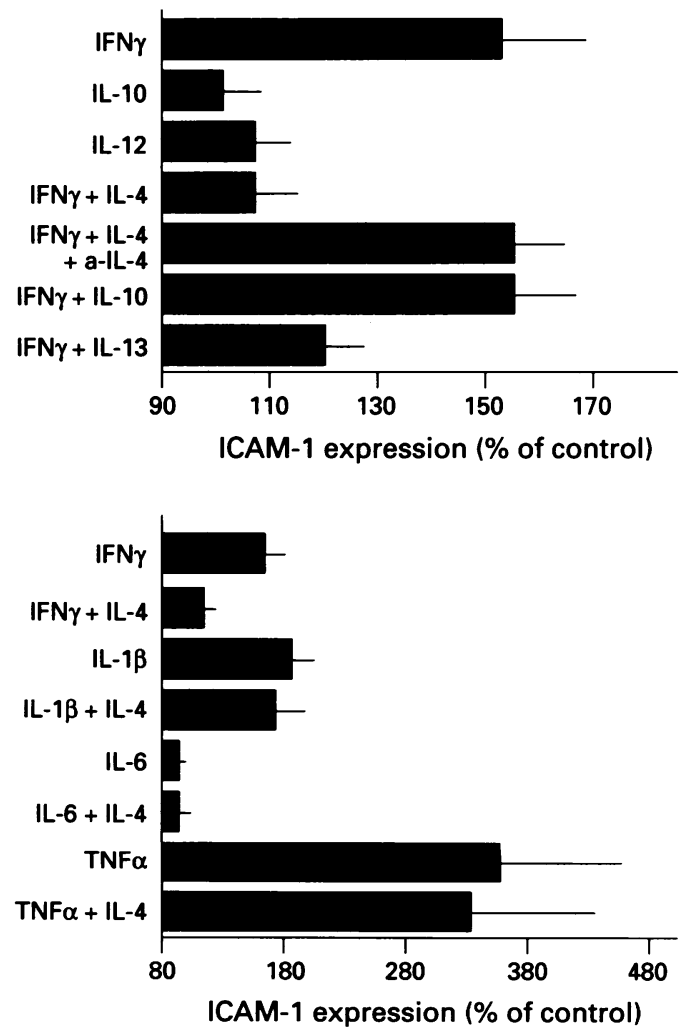

Figure 3 Cytokine mediated modulation of ICAM-1 expression on synovial fibroblasts: results from two representative experiments (note different horizontal scales). Data are mean values (shaded) and SD (open) shown as percentage of the control (background expression in the absence of cytokines $=100 \%$ ). $a-I L-4=$ Antibody to $I L-4$. 


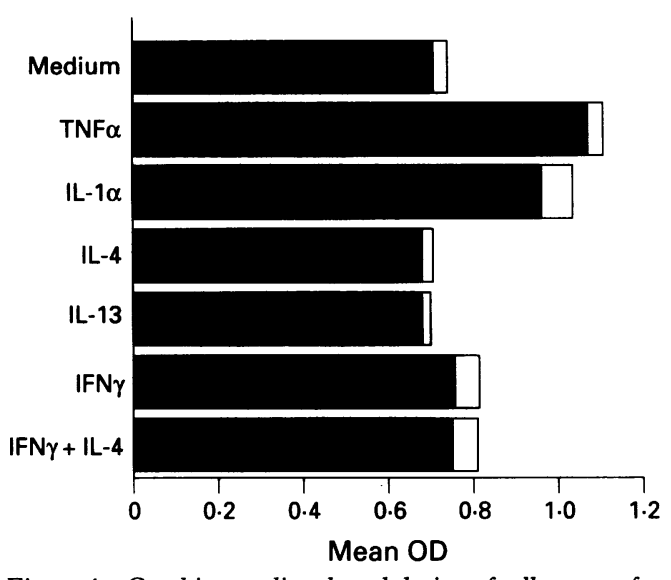

Figure 4 Cytokine mediated modulation of adherence of $P B M C$ s on synovial fibroblasts. Data are mean values (shaded) and SEM (open) of optical densities (OD).

IFN $\gamma$. This is of particular interest, as T cells are thought to play a critical role in the pathogenesis of rheumatoid arthritis and spondyloarthropathies. To understand the role of $T$ lymphocytes in the inflammatory process involved in these diseases, it is necessary to study the influence of lymphokines secreted by these cells on effector cells such as synovial fibroblasts in the joint. Our data show that the Th1 lymphokine IFN $\gamma$ can induce expression of ICAM-1, an important molecule for $T$ lymphocyte adhesion to fibroblasts, and that this effect can be antagonised by the Th2 cytokines IL-4 and IL-13. These results contrast with data from epidermal fibroblasts in which IL-4 induced increased ICAM-1 expression. ${ }^{39}$ Nevertheless, the biological relevance of these phenomena is questionable, as IL-4 and IL-13 had no effect on IFNy induced increased adherence of PBMC to synovial fibroblasts. This could be because adhesion molecules other than ICAM-1 are responsible for IFNy induced increased adhesion; they, in turn, may be regulated in a different manner.

It can be speculated that a Th2-like cytokine environment, which is detectable in the synovial fluid of some patients with rheumatoid arthritis (Schlaak et al, manuscript in preparation), has suppressive effects on the interaction between $T$ lymphocytes and synovial fibroblasts. Nevertheless, the Th2 cytokines IL-4 and IL-13 have differential effects, as they can induce the production of the proinflammatory cytokine, IL-6. The pathophysiological relevance of these findings remains to be determined, as in vitro studies cannot reproduce the complex cytokine environment present in the synovial fluid. In addition, our experiments showed that IL-1 $\beta$ and TNF $\alpha$ have a greater potential to activate synovial fibroblasts compared with the Th1 and Th2 cytokines IFN $\gamma, \mathrm{IL}-4$, and IL-13. Monocytes are a major source of $\mathrm{IL}-1 \beta$ and TNF $\alpha$. It is known that monokine production can be effectively downregulated by the Th2 cytokines IL-4, IL-10, and IL-13; these mediators may thus have indirect suppressive effects on cytokine production by synovial fibroblasts. In view of this finding, the direct stimulatory effect of IL-4 and IL-13 on cytokine production by synovial fibroblasts could be interpreted as a mechanism to maintain homeostasis in the cytokine environment. Our findings showed that the effects of IL-4 and IL-13 are not mediated via the same receptor molecule (fig 2), but this does not exclude the possibility that the IL-4 and IL-13 receptor molecules use the same intracellular signal transduction pathways.

It has been shown that the type of $T$ helper response is influenced by the cytokines present at the primary stimulation of a $\mathrm{T}$ lymphocyte. $^{32} 4041$ IFN $\alpha$, IFN $\gamma$, and IL-12, in the absence of IL-4, lead to the development of a Th1-type immune response. IL-4 and IL- $10^{42}$ favour the induction of Th2-like $T$ helper lymphocytes. Until now, no data have been available concerning the capability of synovial fibroblasts to produce the immunoregulatory cytokines IL-10 and IL-12. As our experiments indicate that these cytokines are not secreted by these cells, it may be concluded that synovial fibroblasts do not influence the type of $\mathrm{T}$ helper response. Experiments using supernatants of stimulated or unstimulated fibroblasts are needed to confirm this.

In summary, our data show that monokines, in addition to Th1 and Th2 lymphokines, can modulate the function of synovial fibroblasts. This is of particular interest because the cytokines studied are found in increased concentrations in the synovial fluid of patients with rheumatoid arthritis and spondyloarthropathies.

This work was supported by the Deutsche Forschungsgemeinschaft (project Schl 377/1-1).

1 Remick D G, DeForge L E, Sullivan J F, Showell H J. Profile of cytokines in synovial fluid specimens from patients with arthritis. Interleukin 8 (IL-8) and IL-6 correlate with inflammatory arthritides. Immunol Invest 1992; 21: 321-7.

2 Waage A, Kaufmann C, Espevik T, Husby G. Interleukin-6 in synovial fluid from patients with arthritis. Clin Immunol Immunopathol 1989; 50: 394-8.

3 Xu W D, Firestein G S, Taetle R, Kaushansky K, Zvaifler $\mathrm{N}$ J. Cytokines in chronic inflammatory arthritis. II. Granulocyte-macrophage colony-stimulating factor in rheumatoid synovial effusions. $\mathcal{F}$ Clin Invest 1989; 83: 876-82.

4 Peichl P, Ceska M, Effenberger F, Haberhauer G, Broell H, Lindley I J. Presence of NAP-1/1L-8 in synovial fluids indicates a possible pathogenic role in rheumatoid arthritis. Scand f Immunol 1991; 34: 333-9.

5 Roux Lombard P, Punzi L, Hasler F, et al. Soluble tumor necrosis factor receptors in human inflammatory synovial fluids. Arthritis Rheum 1993; 36: 485-9.

6 Henderson B, Thompson R C, Hardingham T, Lewthwaite $\mathrm{J}$. Inhibition of interleukin-1-induced synovitis and articular cartilage proteoglycan loss in the rabbit knee by Cytokine 1991; 3: 246-9.

7 Matsuoka N, Eguchi K, Kawakami A, et al. Phenotypic characteristics of $\mathrm{T}$ cells interacted with synovial cells. $\mathcal{F}$ characteristics of T cells interacte
Rheumatol 1991; 18: 1137-42.

8 Harigai M, Hara M, Kitani A, et al. Interleukin 1 and tumor necrosis factor-alpha synergistically increase the production of interleukin 6 in human synovial fibroblast. f Clin Lab Immunol 1991; 34: 107-13.

9 Bedard P A, Golds E E. Cytokine-induced expression of mRNAs for chemotactic factors in human synovial cells and fibroblasts. F Cell Physiol 1993; 154: 433-41.

10 Koch A E, Kunkel S L, Harlow L A, et al. Enhanced production of monocyte chemoattractant protein-1 in theumatoid arthritis. F Clin Invest 1992; 90: 772-9.

11 Bucala R, Ritchlin C, Winchester R, Cerami A. Constitutive production of inflammatory and mitogenic cytokines by rheumatoid synovial fibroblasts. $\mathcal{F}$ Exp Med 1991; 173: 569-74.

12 Hamilton J A, Waring P M, Filonzi E L. Induction of leukemia inhibitory factor in human synovial fibroblasts by II- 1 and tumor necrosis factor-alpha. F Immunol 1993; 150: 1496-502.

13 Panayi G S, Lanchbury J S, Kingsley G H. The importance of the $T$ cell in initiating and maintaining the chronic 
synovitis of rheumatoid arthritis. Arthritis Rheum 1992; 35: 729-35.

14 Diamantstein T, Eckert R, Volk H D, Kupier Weglinski $J W$. Reversal by interferon-gamma of inhibition of $\mathrm{J}$ W. Reversal by interferon-gamma of inhibition of delayed-type hypersensitivity induction by anti-CD4 or
anti-interleukin 2 receptor (CD25) monoclonal antibodies. Evidence for the physiological role of the $\mathrm{CD4}^{+} \mathrm{TH}^{+}$subset in mice. Eur $\mathcal{F}$ Immunol 1988: 18: 2101-3.

15 Boom W H, Liano D, Abbas A K. Heterogeneity of helper/ inducer T lymphocytes. II. Effects of interleukin 4- and interleukin 2-producing $T$ cell clones on resting $B$ lymphocytes. F Exp Med 1988; 167: 1350-63.

16 Schlaak J F, Hermann E, Ringhoffer M, et al. Predominance of Thl-type $\mathrm{T}$ cells in synovial fluid of patients with Yersinia-induced reactive arthritis. Eur f Immunol 1992; 22: $2771-6$.

17 Schlaak J F, Buslau M, Jochum W, et al. T cells involved in psoriasis vulgaris belong to the Thl subset. $\mathcal{f}$ Invest in psoriasis vulgaris belon

18 Haanen J B A G, De Waal Malefijt R, Res P C M, et al. Selection of a human $T$ helper type 1-like $T$ cell subset by mycobacteria. $\mathcal{F} \operatorname{Exp}$ Med 1991; 174: 583-92.

19 Yssel H, Shanafelt M-C, Soderberg C, Schneider P V, Anzola J, Peltz G. Borrelia burgdorferi activates a T helper type 1-like $T$ cell subset in Lyme arthritis. f Exp Med 1991; 174: 593-601.

20 Wierenga E A, Snoek M, Jansen H M, Bos J D, van Lier R A, Kapsenberg M L. Human atopen-specific types 1 and 2 T helper cell clones. $\mathcal{f}$ Immunol 1991; 147: 2942-9.

21 Moore K W, Vieira P, Fiorentino D F, Trounstine M L, Khan T A, Mosmann T R. Homology of cytokine synthesis inhibitory factor (IL-10) to the Epstein-Barr virus gene BCRFI. Science 1990; 248: 1230-4.

22 O'Garra A, Stapleton G, Dhar V, et al. Production of cytokines by mouse B cells: B lymphomas and normal B cells produce interleukin 10. Int Immunol 1990; 2: 821-32.

23 Heinzel F P, Sadick M D, Mutha S S, Locksley R M. Production of interferon gamma, interleukin 2, interleukin 4 , and interleukin 10 by $\mathrm{CD} 4+$ lymphocytes in vivo during healing and progressive murine in vivo during healing and progressive murine

24 Fiorentino D F, Zlotnik A, Mosmann T R, Howard M, O'Garra A. IL-10 inhibits cytokine production by activated macrophages. F Immunol 1991; 147: 3815-22.

25 Enk A H, Katz S I. Identification and induction of keratinocyte-derived IL-10. $\mathcal{f}$ Immunol 1992; 149: 92-5.

26 Ding L, Shevach E M. IL-10 inhibits mitogen-induced T cell proliferation by selectively inhibiting macrophage costimulatory function. 7 Immunol 1992; 148: 3133-9.

27 de Waal Malefyt R, Haanen J, Spits H, et al. Interleukin 10 (IL-10) and viral IL-10 strongly reduce antigen-specificity human $T$ cell proliferation by diminishing the antigenhuman T cell proliferation by diminia downregulation of presenting capacity of monocytes via downregulation of
class II major histocompatibility complex expression. $\mathcal{f}$ Exp Med 1991; 174: 915-24.
28 Rousset F, Garcia E, Defrance T, et al. Interleukin 10 is a potent growth and differentiation factor for activated human B lymphocytes. Proc Natl Acad Sci USA 1992; 89: 1890-3.

29 Mengel J, Dare L, Dare G M, et al. An activated murine $B$ cell lymphoma line (A-20) produces a factor-like
activity which is functionally related to human natural activity which is functionally related to human natural killer cell

30 Trinchieri G, Rengaraju M, D'Andrea A, et al. Producer cells of interleukin-12. Immunol Today 1993; 14: 237-8.

31 Wu C Y, Demeure C, Kiniwa M, Gately M, Delespesse G. IL-12 induces the production of IFN-gamma by neonatal human CD4 T cells. $\mathcal{F}$ Immunol 1993; 151: 1938-49.

32 Manetti R, Parronchi P, Giudizi M G, et al. Natural killer cell stimulatory factor (interleukin 12 [IL-12]) induces $T$ helper type 1 (Th1)-specific immune responses and inhibits the development of $\mathrm{IL}-4$-producing Th cells. $f$ Exp Med 1993; 177: 1199-204.

33 Minty A, Chalon P, Derocq J M, et al. Interleukin-13 is a new human lymphokine regulating inflammatory and immune responses. Nature 1993; 362: 248-50.

34 Briolay J, Dechanet J, Blanchard D, Banchereau J, Miossec P. Interleukin 4 inhibits polyclonal immunoglobulin secretion and cytokine production by peripheral blood mononuclear cells from rheumatoid arthritis patients. $\mathcal{f}$ Clin Immunol 1992; 12: 36-44.

35 Punnonen J, Aversa G, Cocks B G, et al. Interleukin 13 induces interleukin 4-independent IgG4 and IgE synthesis and CD23 expression by human B cells. Proc Natl Acad Sci USA 1993; 90: 3730-4.

36 Abrahamsen T G, Johnson P M, Natvig J B. Membrane characteristics of adherent cells dissociated from characteristics of adherent cells dissociated from rheumatoid

37 Pearce-Pratt R, Phillips D M, Bourinbaiar A S. Simple colorimetric cell-cell adhesion assay using biotinylated lymphocytes. F Immunol Methods 1991; 140: 159-65.

38 Zurawski S M, Vega F Jr, Huyghe B, Zurawski G. Receptors for interleukin-13 and interleukin-4 are complex and share a novel component that functions in signal transduction. EMBO ₹ 1993; 12: 2663-70.

39 Piela-Smith T H, Broketa G, Hand A, Korn J. Regulation of ICAM-1 expression and function in human dermal of ICAM-1 expression and function in human dert

40 van der Pouw-Kraan T, de Jong R, Aarden L. Development of human Th1 and Th2 cytokine responses: the cytokine production profile of $\mathrm{T}$ cells is dictated by the primary in vitro stimulus. Eur f Immunol 1993; 23: 1-5.

41 Maggi E, Parronchi P, Manetti R, et al. Reciprocal regulatory effects of IFN-gamma and IL-4 on the in vitro development of human Th1 and Th2 clones. $\mathcal{F}$ Immunol 1992; 148: 2142-7.

42 Hseih C S, Heimberger A B, Gold J S, O'Garra A, Murphy $K M$. Differential regulation of $T$ helper phenotype development by interleukins 4 and 10 in an alpha beta T-cell-receptor transgenic system. Proc Natl Acad Sci USA 1992; 89: 6065-9. 